\title{
Structural change and productivity growth in Brazil: where do we stand?
}

\author{
Mudança estrutural e crescimento da \\ produtividade no Brasil: onde estamos?
}

\author{
ANDRÉ NASSIF* \\ LUCILENE MORANDI ${ }^{+}$ \\ ELIANE ARAÚJO ${ }^{++}$ \\ CARMEM FEIJÓ $^{x}, x x$
}

\begin{abstract}
RESUMO: O objetivo deste artigo é discutir a evolução da produtividade do trabalho brasileira nas décadas de 1990 e 2000, para lançar luz sobre a resiliência da economia brasileira em recuperar o crescimento. O crescimento da produtividade do trabalho no Brasil, após mostrar taxas anuais positivas entre 1950 e 1979, ficou estagnado após 1980. Seguindo a metodologia de McMillan e Rodrik (2011), este artigo inicialmente decompõe o crescimento da produtividade do trabalho no período 1950-2011, de acordo com o componente 'structural change' (potencializador de crescimento) e o 'within effect' (que reduz o crescimento, se não for acompanhado por uma mudança estrutural significativa enquanto o país ainda estiver em processo de catching-up). A seguir, é apresentado um exercício econométrico para explicar os determinantes do componente 'structural change' no período 1995-2011. Os resultados mostram que a estagnação da produtividade brasileira é explicada pela tendência de supervalorização da moeda brasileira, pela reprimarização da cesta de exportação, pelo baixo grau de abertura comercial do Brasil e pelas altas taxas de juros reais vigentes no período.
\end{abstract}

PALAVRAS-CHAVE: Desenvolvimento econômico; catching-up; crescimento da produtividade do trabalho; mudança estrutural.

\footnotetext{
* Departamento de Economia da Universidade Federal Fluminense - UFF, Rio de Janeiro/RJ, Brasil. E-mail: andrenassif27@gmail.com. ORCID: 0000-0001-9456-0372.

+ Departamento de Economia da Universidade Federal Fluminense - UFF, Rio de Janeiro/RJ, Brasil. E-mail: 1morandi@id.uff.br. ORCID: 000-0002-3943-6229.

++ Departamento de Economia da Universidade Estadual de Maringá - UEM, e CNPq, Maringá/PR, Brasil. E-mail: elianedearaujo@gmail.com). Orcid: 0000-0001-5104-2508.

x Departamento de Economia da Universidade Federal Fluminense - UFF e CNPq, Rio de Janeiro/RJ, Brasil. E-mail: cbfeijo@gmail.com, ORCID: 0000-0002-6376-4599.

xx Paper presented to the 4th Workshop on "New Developmentalism: New theory and policy for developing countries", of Fundação Getulio Vargas. July 25 and 26, 2019. Submitted: 25/July/2019; Approved: 1/August/2019.
} 
ABSTRACT: The aim of this paper is to discuss the evolution of the Brazilian labour productivity in the 1990s and 2000s to shed some light on the resilience of the Brazilian economy to recover growth. Labor productivity growth in Brazil, after showing positive annual rates between 1950 and 1979, became stagnant after 1980. Following McMillan and Rodrik's (2011) methodology, this paper at first decompose labor productivity growth in the period 1950-2011, according to "structural change" (which is considered growth-enhancing) and "within effect" (which is growth-reducing, if not accompanied by significant structural change while the country is still pursuing its catching-up process). Next, an econometric exercised is presented to explain the determinants of the structural change component of the labour productivity since economic opening in the 1990s. The results show that the stagnation of the Brazilian productivity is explained by the overvaluation trend of the Brazilian currency, the reprimarization of the export basket, the low degree of Brazil's trade openness and the high real interest rates prevailing in the period.

KEYWORDS: Economic development; catching-up; labor productivity growth; structural change.

JEL Classification: 010; 011; 014; 047.

\section{INTRODUCTION}

The Brazilian economy has shown low resilience to grow since the 2015-2016 recession. The cumulative decline of $6.7 \%$ of GDP in the biennium is far from being offset by the $1.1 \%$ growth rate observed in 2017 and in 2018, and by official forecasts for 2019 so far (September 2019), around less than 1.0\%. Besides, these disappointing results and expectations have a direct impact on the labor market. The year 2018 registered more than 12 million unemployed in the country with increasing precariousness in the creation of new jobs, mostly in the low skill activities. In this paper, we will argue that in order to understand the difficulty of the recent recovery of the Brazilian economy one must take into account the process of premature deindustrialization observed throughout the 1990s and 2000s. According to the structuralist and new-developmentalist views, the loss of importance of the manufacturing sector in the productive structure has important implications for the economy's aggregate productivity performance, because it limits the positive spillovers of productivity gains from the manufacturing industry throughout the economy. In the absence of these sustained gains, long-term growth is jeopardized.

The Brazilian economic development since the end of World War II illustrates a case in which labor productivity growth, after showing sustained annual positive rates between 1950 and 1979, became stagnant (as did the long-term economic growth) after 1980. Actually, economic stagnation started way before the country ever reached a high per capita income level. This suggests that the long-term stagnation of the Brazilian economy is related to premature deindustrialization, a process through which the relative loss of importance of the manufacturing sector is followed by a sharp reallocation of labor from both the primary (the traditionally low 
productivity sector) and the manufacturing (the higher productivity sector) sectors to segments of low productivity and low skilled labor in the service sector.

We will argue that, between 1950 and 1979, the positive evolution of the Brazilian labor productivity was the result of a fine coordination of economic policies - industrial and technological as well as macroeconomic policies. The period during which labor productivity became stagnant, on its turn, coincided with a weak harmonization between industrial policy and the macroeconomic policies, especially after 1999, when Brazil adopted a very orthodox arrangement of monetary, fiscal and exchange rate policies (Nassif, Bresser-Pereira and Feijó, 2018).

Notwithstanding the importance of the coordination of the economic policies to explaining long-term growth, the new-developmentalist literature points out that the productive structure matters. In order to test those hypotheses, we will use the methodology proposed by McMillan and Rodrik (2011), who decompose the average labor productivity growth into two components: the "between effect" (or "structural change") component, and the "within effect" component. The between effect component is driven by a reallocation of labor from the primary to the manufacturing sectors (or, if it is the case, also to the higher labor productivity segments of the service sector), while the within effect component is explained by sectoral characteristics, such as the capital-labor ratio and technical progress. According to the interpretation of McMillan and Rodrik (2011), during the process of catching-up, if a country's labor productivity growth is driven by structural change, it will be "growth-enhancing," whereas if a country's labor productivity growth is commanded by sectoral or within change, but such process is not also accompanied by significant "structural change", it will be "growth-reducing."

The remainder of this paper is organized as follows. Second section briefly discusses the theoretical issues related to structural change, economic development and long-term stagnation in countries that suffer from premature deindustrialization. The third section presents a brief review on economic policies adopted in Brazil over the import substitution period (1950-1989) and after trade liberalization and other liberalizing reforms (1990-2018). Fourth section presents statistical evidence on the Brazilian labor productivity growth in the period 1950-2011, ${ }^{1}$ 1950-1979 (the growth period) and 1980-2011 (the stagnant period) according to structural change (growth-enhancing) and within (growth-reducing) components as proposed by McMillan and Rodrik's (2011) methodology. By assuming that there is a relative consensus that stagnation in the subperiod 1980-1994 was explained by the external debt crisis and chronic inflation rates that practically paralyzed the Brazilian economy, fifth section regress the "structural change" component on several microeconomic and macroeconomic variables between 1995 and 2011 to specifically investigate the factors explaining Brazil's labor productivity stagnation since 1995. Finally, the last section draws the main conclusions.

\footnotetext{
${ }^{1}$ At the time of carrying out this study, the compatible database ended in 2011.
} 


\section{STRUCTURAL CHANGE, ECONOMIC DEVELOPMENT AND DEINDUSTRIALIZATION}

The post-war economic history has shown that a country can overcome economic underdevelopment by developing and diversify its manufacturing structure. Such structural change may not be, however, enough to catch-up. This means that the process of economic development and catching-up, which implies reaching high levels of productivity and per capita income near the average of those countries considered rich, will be successful if, and only if, the average growth rate of productivity over time is high enough to prevent premature deindustrialization and recurrent balance of payments crisis. In other words, a country can overcome underdevelopment, but can be locked-in at developing stage conditions for many decades or even forever. If this is the case, the country faces a long-term economic stagnation that is not the result of an "average income trap," but of inconsistent economic policies adopted for the decades to come.

Within the framework of the structuralist approach, there is a long tradition of theoretical models of development in which the interaction of factors related to demand and supply explain the rate of productivity growth in the long run. The seminal lectures by Kaldor in the 1960s set the basis for the discussion about the relevance of the manufacturing industry in the productive structure to enhance growth through a cumulative causation process. Later on, Dixon and Thirwall (1975) formalized Kaldor's proposition, explaining how the cumulative causation process affects the development of an economy through the effect of growth driven by demand impacting on the competitiveness of the export sector and the increase in exports feeding back productivity growth.

Therefore, the Kaldorian growth models explain long-term growth as a complex phenomenon arising from factors related to both supply and demand and describe economic development as characterized by stylized facts or empirical regularities (Ros, 2013; McCombie and Thirlwall, 1994).

The list of stylized facts may be relatively long, but for this paper, two stand out (see Ros, 2013, ch.1). The first stylized fact describes the beginning of the industrialization process, and refers to the movement through which productive resources, especially labor, are gradually reallocated from the traditional, low-productivity agrarian sector to the modern industrial sector, which presents higher capital endowment per worker and with greater backward and forward linkages with other sectors of the economy. Thus, the industrialization process occurs through a structural change towards higher productivity and technological sophisticated economic segments.

A second stylized fact identifies that the manufacturing sector, by the stronger presence of static and dynamic economies of scale, ${ }^{2}$ pushes and sustain the rise in

\footnotetext{
${ }^{2}$ Static economies of scale occur when the unit costs of a firm, within a segment or in the manufacturing industry as a whole, are reduced due to an increase in production scales in response to increased
} 
average productivity rates in the economy as a whole. As long as the productive structure evolves towards becoming more complex and diversified, with greater interaction among the various industries, productivity gains in more dynamic sectors (e.g., the manufacturing industry and the services associated with it) will spread to other sectors, increasing the growth potential of the economy. ${ }^{3}$ Thus, a complex and diversified economy must have higher productivity growth rates than economies with less complex productive structures specialized in the production of goods and services with low technological content.

These two stylized facts allow us to identify a situation of premature deindustrialization, when a regressive change in the productive structure may lead to a decline in the importance of the manufacturing sector to drive the growth of the economy's productivity. In this case, labor migration to lower productivity sectors must be observed and the economy loses its structural traction to continue growing with positive and sustainable productivity gains in the long run. The forward and backward links weaken.

When the development process is interrupted by premature deindustrialization, the relative loss of importance of the manufacturing sector occurs before the economy has reached the stage of fully exploiting the scale gains provided by the dynamics of the industrial transformation sector. Therefore, and this is the point of interest in this paper, when structural change is characterized by the reallocation of labor force towards low skill activities signaling that a premature deindustrialization process might be in course, a crucial question to be raised is which economic forces reinforce this process. Bresser-Pereira $(2016,2019)$ has shown that throughout the process of economic development, it is crucial that the two main macroeconomic prices (real interest rate and real exchange rate) are maintained tendentiously at their respective correct levels. This means that the average real interest rate should remain at a level below the average rate of return on capital and that the real exchange rate should keep the currency slightly undervalued. The need for keeping these two fundamental macroeconomic prices at their correct level is one of the central theses of the New Developmentalism when arguing in favor of reindustrialization to promote the catching-up. In sum, in line with the New Developmentalism approach, structural change oriented to promote the development and fight stagnation should be analyzed as the result of well coordinated economic policies.

investments. Dynamic economies of scale occur when the unit costs of a firm, within a segment or in the manufacturing industry as a whole, are reduced due to an increase in production scales in response to increased technological capacity building.

\footnotetext{
${ }^{3}$ This is the so-called Kaldor-Verdoorn law, according to which the higher the growth rate of industrial output (in value added), the higher the growth rate of industrial productivity. Since productivity growth in the non-industrial sectors depends on productivity growth in the industrial sector, this is, in the end, the main determinant of the rate of change of the average productivity of the economy as a whole. See Kaldor (1966) and McCombie and Thirlwall (1994, ch. 2).
} 


\section{BRAZIL'S ECONOMIC POLICIES SINCE THE IMPORT SUBSTITUTION PERIOD: AN OVERVIEW}

From the mid-1950s to 1979, industrial and trade policies pursued an import substitution strategy (IS) in Brazil. In each step of the IS process, governments targeted some industries as industrial policy priorities and combined high tariffs, import licenses and export subsidies (these latter especially after the 1970s) to protect the Brazilian manufacturing sector and boost exports of manufactured goods. In practice, the import license regime was only eliminated with trade liberalization in March 1990.4 Another peculiarity of the industrial policy is that the country has always been open to foreign direct investment (FDI) driven by multinational enterprises (MNE). Rather than focusing on technology transfer and technological spillovers, policies for attracting MNEs in Brazil targeted on the implementation of import substitution and, hence, aimed at reducing both technology and import dependencies related to balance of payments. Such a strategy contrasts with some Asian countries, such as Singapore and China, that were traditionally open to FDI inflows, but conditioned them to transfers of technology to local firms through joint-ventures, research and development $(R \& D)$ collaboration and other arrangements.

Despite all the imperfections of the protectionist policies of the IS period, there is no doubt that they created the conditions for developing a diversified manufacturing sector in Brazil. ${ }^{5}$ Although we recognize that such heavy protectionist measures have jeopardized the efficiency in the allocation of resources, it is clear that such static microeconomic inefficiencies were more than offset by the significant dynamic efficiencies of the Brazilian economy. In fact, between 1950 and 1979, labor productivity grew at $4.4 \%$ per year, on average, while Brazil's real GDP boomed at $7.3 \%$ per year, on average, in the same period. Moreover, the labor productivity growth was accompanied by a sharp increase $(3.3 \%$ per year, on average) in employment. ${ }^{6}$

Like most Latin American countries, Brazil's development strategies were highly dependent on foreign savings, especially through long-term foreign lending. The shock of international interest rates between 1979 and 1982 led Brazil and

\footnotetext{
${ }^{4}$ An import license as a sine qua non condition for an import to be approved lasted from 1947 to 1970 , when the former was replaced by the "guia de importação" (an import document issued by the Foreign Trade Department, CACEX). Although the creation of this document has been justified for fulfilling statistical purposes, in practical terms it continued to work as an instrument of administrative import control. See Nassif (1995).

${ }^{5}$ For a comparison between Brazil and several developing countries, see Amsden (2001).

${ }^{6}$ Data on labour productivity growth were calculated by the authors, based on the Groningen Growth and Development Centre Database (https://www.rug.nl/ggdc/productivity/10-sector/). Access on January 8,2019 . Data on Brazil's real GDP growth was extracted from the Brazilian Institute of Geography and Statistics (IBGE).
} 
most other Latin American countries into a deep crisis (the external debt crisis) that lasted until the beginning of the following decade.

In fact, the eruption of the external debt crisis in 1980, which led to the collapse in international private capital flows to Latin American countries in 1982, meant a complete disconnection among industrial, trade and macroeconomic policies. These policies subsequently lost their most efficient tools for promoting catching-up in Brazil. In fact, since a large amount of annual expenditures on external debt (principal plus interest expenditures) had to be paid, trade policies, especially import policy, became a powerful instrument for saving foreign exchanges - rather than being an industrial policy tool. Despite a program of tariff reduction having been adopted in 1988, the prevalence of several non-tariff barriers implied that the effective protection in Brazil was practically unchanged (Kume, Piani and Souza, 2000). A definitive trade liberalization program would be only adopted in the early 1990s.

Between March 1990 and December 1994, together with other liberalizing reforms, such as financial deregulation and opening of the capital account, Brazil adopted a unilateral trade liberalization. Trade liberalization was characterized by the elimination of most non-trade barriers (NTBs) and a relatively rapid tariff reduction. ${ }^{7}$ Comparatively to other experiences of trade liberalization in developing countries during the 1980s and the 1990s, the Brazilian trade reform represented a deep microeconomic shock for three reasons: first, it was concluded in a relatively short period of time (around 4 years), differently from South Korea and India, whose trade liberalization reforms lasted around 5 (from 1983 to 1988) and more than 10 years (from 1991 on), respectively; second, contrary to the recommendations of trade liberalization literature, the elimination of NTBs and the reduction of import tariffs were jointly introduced, and trade reform was adopted together with the liberalization of the capital account as well as within a context of sharp overvaluation of the Brazilian currency; ${ }^{8}$ and third, again, differently from South Korea and India, which preserved industrial policy together with their trade liberalization programs as a strategy for pursuing catching-up, industrial policy practically disappeared from the government's policy focus in Brazil between 1990 and the early 2000s, even after the conclusion of trade reform.

Despite the negative microeconomic shocks, several studies show sound empirical evidence that between 1990 and 1998 labor productivity registered significant annual average growth rates in Brazil, 9 reversing the low and stagnant an-

\footnotetext{
${ }^{7}$ Between 1989 and 1994, while the average nominal import tariff for all goods in Brazil was reduced from $39.6 \%$ to $11.2 \%$, the standard deviation dropped from $14.6 \%$ to $5.9 \%$ in the same period. See Kume, Piani and Souza (2000: 11) and Abreu (2004).

${ }^{8}$ On the recommended sequence and speed for trade liberalization, see Bhagwati (1978) and Michaely, Papageorgiu and Choski (1991). For Brazil and South Korea, see Moreira (1995). For Brazil and India, see Nassif $(2003,2007)$.

${ }^{9}$ See, for instance, Feijo and Carvalho (2002), Nassif (2005), Kupfer (2005).
} 
nual average growth rates shown in the previous decade (the so-called "lost decade" of the 1980s, a period of external debt crisis and chronic inflation). ${ }^{10}$ Unlike what had been observed between 1950 and 1979, the gains from productivity in the aftermath of the Brazilian trade liberalization resulted essentially from a static reallocation of resources, rather than from dynamic change.

By the end of the 1990s, Brazilian average import tariff remained practically unchanged, while industrial policy was almost completely absent. However, from 2004 on, during Lula da Silva's (2003-2010) and Dilma Rousseff's governments (2011-2014), industrial policy returned as one of the leading mechanisms for promoting activities considered strategic for accelerating structural change towards scale-engineering-and-knowledge-based industries as well as diversifying productive and export structures. ${ }^{11}$ The three industrial policy programs adopted in this period also aimed at boosting physical investment and innovation in the Brazilian economy. These plans, however, repeated old mistakes and well-known misleading policies that had prevailed during the time of the import substitution period: lack of selectivity and performance requirements from entrepreneurs who benefited from public incentives; an excessive use of public subsidies as the main instrument of governmental support, especially credit subsidies from the Brazilian Development Bank (BNDES); and, last but not least, a weak coordination among industrial, trade and macroeconomic policies. ${ }^{12}$

Actually, the emphasis on price stabilization as the main target of economic policy and the country's high degree of openness to capital flows, put the Brazilian economy in a vicious cycle. In fact, the macroeconomic arrangement of economic policy, based on the inflation target regime, implies that in the face of increasing inflation expectations, the central bank immediately reacts by driving short-term policy rates upwards. If other macroeconomic indicators are relatively sound (as of 2005 in Brazil), and given the absence of mechanisms for capital control, the increasing differential between domestic and foreign interest rates attracts excessive net capital inflows. Consequently, the Brazilian domestic currency tends to appreciate in nominal and (given the unchanged price level in the very short run) real terms. As the main transmission of monetary policy in Brazil is through the real exchange rate, ${ }^{13}$ inflation expectations and actual inflation tend to match the annual target, but in the meantime, if there is any domestic or external shock, the country faces capital flight and sharp nominal and real currency depreciation. To minimize the pass-through of the higher costs of depreciation to prices and deter capital flight as well, the central bank is obliged to increase nominal short-term policy rates again. In short, although the inflation targeting regime provides apparent short-term price

\footnotetext{
${ }^{10}$ Since the early 1980s, Brazil was suffering from a chronic inflation process, which would only be definitively stabilized in 1994, with the Real Plan (Plano Real).

${ }^{11}$ For an analysis of the three programs of industrial policy adopted between 2004 and 2011, see Coutinho et al. (2012) and Castilho and Miranda (2017).

12 On this late issue, see Nassif, Bresser-Pereira and Feijó (2018).

${ }^{13}$ See Nassif, Feijó and Araújo (2019).
} 
stability, in the long run neither price stability nor economic growth is assured. This can be illustrated by Figure 1, that compares the movement of ex-post short-term real interest rates (in percentage on the right axis) and real exchange rates (in index numbers on the left scale) between 1999 and 2018.

Figure 1: Ex-post short-term real interest rates (in percentage) and real effective exchange rate indices in Brazil, 1999-2018

$(1994=100)$

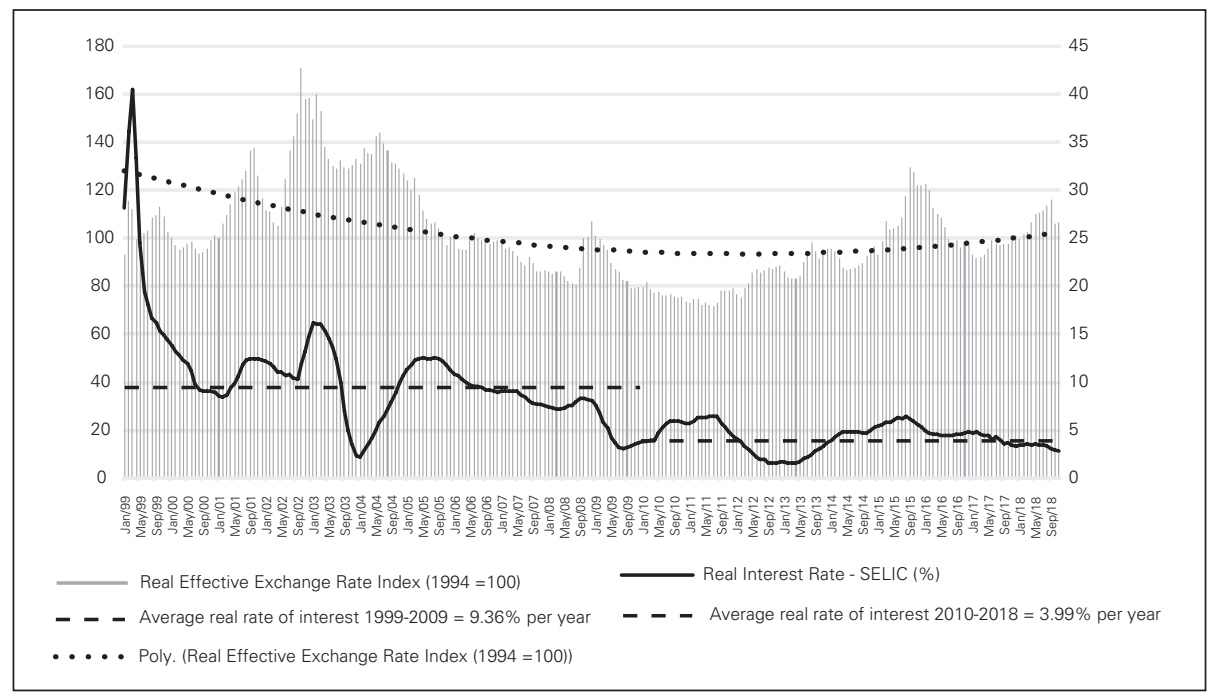

Source: Central Bank of Brazil for short-term nominal interest rates and real effective exchange rate indices. Brazilian Institute of Geography and Statistics (IBGE) for consumer inflation rate (IPCA). Real interest rates (SELIC) calculated by the authors and deflated by IPCA.

Despite the real interest rate dropping to a historically low level at the end of 2018 (around 2.9\% per year), the average that prevailed between 1999 and 2018 was very high $(7.7 \%$ per year), compared with that which prevailed in developed and many other developing countries. Figure 1 also shows that the average real interest rate (the broken lines) over the 2000s was much higher $(9.4 \%$ per year between 1999 and 2009) than that of the 2010s (4\% per year between 2010 and 2018). The Figure 1 also clearly shows a marked trend of real appreciation of the Brazilian currency between the end of 2005 and the beginning of 2015 (the dotted line). In mid-2011, the level of overvaluation reached almost $30 \%$ in relation to the long-term real exchange rate equilibrium. As shown by Nassif, Feijó and Araújo (2017), this misalignment has only been corrected by the sharp depreciations observed in the aftermath of domestic or international shocks.

The most damaging consequences of the overvaluation trend of the Brazilian currency throughout the 2000s were not only the aggravation of Brazil's premature deindustrialization (Nassif, Feijó and Araújo, 2015; Nassif, Bresser-Pereira and Feijó, 2018), a phenomenon that had begun in the mid-1980s (Nassif, 2008), but 
also a sharp reprimarization of the country's export basket. Between 2000 and 2016, the share of manufactured goods in Brazil's total exports decreased from around $71 \%$ to $53 \%$, while the share of primary goods in total exports increased from around $26 \%$ to $45 \%$ in the same period (Nassif and Castilho, 2018).

\section{THE BREAKDOWN OF BRAZIL'S LABOR PRODUCTIVITY GROWTH: HAS LABOR PRODUCTIVITY BEHAVIOR BEEN GROWTH-ENHANCING OR GROWTH-REDUCING?}

In this section we will replicate the exercise as proposed by McMillan and Rodrik (2011) to break down the average labor productivity growth into two components: the 'between effect' and the 'within effect'. The between effect (or structural change) component is driven by a reallocation of labor from the primary sector to the manufacturing sector (or, if it is the case, also to the higher labor productivity segments of the service sector); and the within effect component is explained by sectoral characteristics, such as capital-labor ratio, technical progress, etc.

Data on real value added (expressed in 2005 US dollar) and employment were drawn from the Groningen Growth and Development Center (GGDC) database, ${ }^{14}$ for the period 1950-2011. The data is available for nine sectors. However, for our empirical purpose, they were grouped into five major sectors: Agriculture and Mining; Manufacturing; Construction and Energy Infrastructure (construction and utilities, including electricity, gas and water supply); Services of low skilled labor (trade, restaurants and hotels; government services; community, social and personal services); and Services of high skilled labor (transport, storage and communication; finance, insurance, real state and business). The labor productivity y was estimated as the ratio of each sector i's value added (VAit) in time t to the corresponding sectoral employment (EMP) it, as follows:

$$
y=(V A)_{t}^{i} /(E M P)_{t}^{i}
$$

Labor productivity was calculated for three subperiods: $1950-1979$; $1980-$ 1994; and 1995-2011. The first subperiod, 1950-1979, coincides with Brazil's rapid industrialization, with high and sustained investment rates and high rates of GDP growth. The second subperiod, 1980-1994, was that in which the Brazilian economy, like other developing economies in Latin America, suffered from an external debt crisis, a shortage of international credit and very high inflation rates. On account of low investment rates and high inflation, this period marked the beginning of economic stagnation in Brazil. The third subperiod, 1995-2011, cov-

\footnotetext{
${ }^{14}$ For the GGDC 10-Sector Database, see the Groningen Growth and Development Center web page http://www.ggdc.net/databases/10_sector.htm. For more details on the database, see Timmer et al. (2014, 2015). Accessed on June 2, 2018.
} 
ers the period after the stabilization of chronic inflation under the Real Plan (Plano Real, 1994). This subperiod coincided both with China's economic boom as well as its positive impact on commodity prices, and with the 2008 global financial crisis and a sluggish world growth since then.

Figure 2 illustrates the share of sectoral labor in total employment in Brazil in the 1950-2011 period. Contrary to well succeeded experiences of catching-up, Figure 2 registers that, in Brazil, the labor reallocation occurred mainly by displacing employment from Agriculture and Mining to the Services sector, especially to the segments of low skilled labor and lower productivity. The share of employment in Agriculture and Mining in total employment was almost 75\% lower in 2011 compared to 1950, while the share of employment in Services (low and high skilled ones increased $227 \%$ in the same period. With respect to the share of employment in Construction and Energy Infrastructure, this increased by $85 \%$, and in the Manufacturing Sector this share was kept practically unchanged between 1950 and 2011.

Figure 2: Share of sectoral labor in total employment, 1950-2011 (\%)

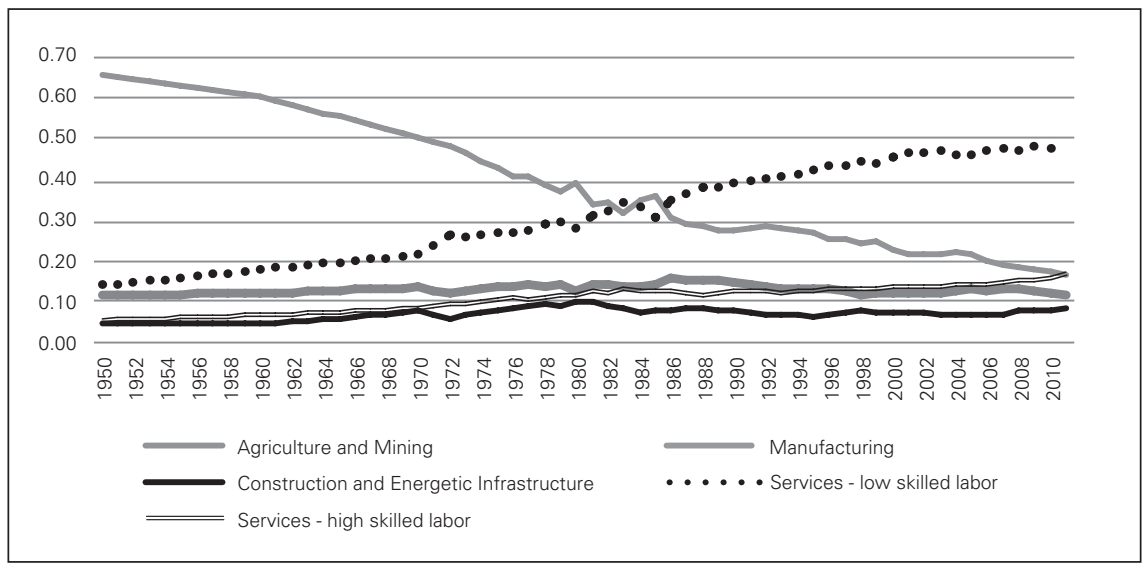

Source: Groningen Growth and Development Center database.

Following McMillan and Rodrik (2011), the decomposition of labor productivity growth can be expressed by:

$$
\Delta Y_{t}=\sum_{i=n} \theta_{i, t-k} \Delta y_{i, t}+\sum_{i=n} y_{i, t} \Delta \theta_{i, t}
$$

where $\Delta$ refers to changes between the periods $t-k$ and $t ; Y_{t}$ is the labor productivity of the economy as a whole; $y_{i, t}$ is the sectoral productivity in period $t$ for each sector $i$; and $\theta_{i, t}$ is the share of employment in sector $i$. The first term is the within component of productivity growth, while the second term captures structural change effect. The decomposition of labor productivity growth may reveal whether its growth dynamics was achieved by labor reallocation from low to high productivity sectors (structural change component) or by technological progress 
(within component). The second term of equation (2) represents the inner product of productivity levels. If changes in employment shares between sectors are positively correlated with productivity levels, this term will be positive, indicating that structural change will have contributed to increasing the economy's aggregate productivity growth.

McMillan and Rodrik (2011) stress that, before a country has reached a level of productive maturity, if its labor productivity gains are predominantly driven by intra-sectoral effects (or "within" change), without having significant "between" effects (or structural change), such efficiency gains will be growth-reducing. In contrast, a developing country will only have labor productivity gains that are growth-enhancing if these gains, although can also result of sectoral effects (within change), are translated into strong between effects (or structural change effects).

The results presented in Figure 3 show that labor productivity behavior in Brazil between 1950 and 1979 was markedly growth-enhancing, for accumulated labor efficiency growth (around 247\%) was commanded by the structural change effect (131 pp.), although the within effect was also significant (116 pp). However, in the 1980s the economy suffered an inflection in the trend of productivity growth: the accumulated labor efficiency growth was negative in the period 1980-1994 $(-19.5 \%)$, while it was only marginally positive in the period $1995-2011(13.5 \%)$, when the within effect prevailed over the structural change effect. As shown in the previous results, from the 1980s on, the reallocation of labor in Brazil occurred mainly from the Agriculture and Mining sectors to the Services of low skilled labor. Such adverse dynamics represented a negative impact on long-term economic growth, undermining the possibility of Brazil reducing the productivity gap with developed economies. Summing up, while the Brazilian economy benefited from a growth-enhancing labor productivity change during the first three decades of industrialization (1950-1979), in the period 1980-2011 the underperformance of labor productivity was unequivocally growth-reducing.

Figure 3: Decomposition of labor productivity in Brazil, 1950-2011

(percentage accumulated over the period)

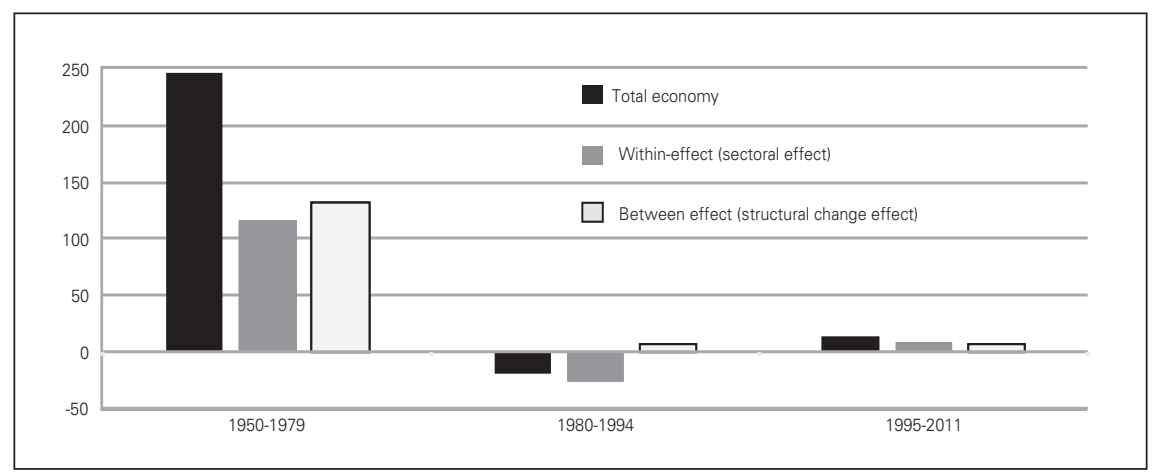

Source: Calculated by the authors, based on Groningen Growth and Development Center database. 


\section{THE MAIN DETERMINANTS OF THE ECONOMIC STAGNATION IN BRAZIL: ECONOMETRIC RESULTS FOR THE STRUCTURAL CHANGE COMPONENT}

In this section we will present the results of our econometric exercise to discuss the determinants of the structure component of the labor productivity growth in the Brazilian economy during the period 1995-2011, when labor productivity growth was stagnant. There is a relative consensus that the stagnation of productivity growth in the subperiod 1980-1994 is explained by the external debt crisis and chronic inflation rates that dominated the macroeconomic scenario and imposed severe restrictions on economic growth. ${ }^{15}$ Once price stabilization had been achieved in mid-1994, and the process of economic opening had been deepened, the expectation was that productivity growth would resume. However, as seen in the previous section, productivity growth continued to be stagnant. In addition, taking into account that the Brazilian economy has not already reached a maturity stage and, therefore, there is high potential for continuing to promote structural change, we are specially interested in investigating the "structural change" component of the productivity growth. Thus, we will regress the "structural change" component of the productivity during the 1995-2011 on several explanatory variables.

Table 1 displays the explanatory variables as well as the expected signs of their respective estimated coefficients. Besides the variables suggested by McMillan and Rodrik (2011), and in line with the new-developmentalist literature, we added others to capture the importance of the macroeconomic prices to Brazil's specific economic context in the period.

Table 1: Explanatory variables of the econometric regressions: dependent variable - structure change component

\begin{tabular}{|l|c|c|}
\hline \multicolumn{1}{|c|}{ Abbreviation } & Explanatory variable & Expected sign \\
\hline LOGLABORSHARE & $\begin{array}{c}\text { Share of employment in the services of } \\
\text { low skilled labor in total employment }\end{array}$ & - (negative) \\
\hline LOGPRIMARYEXPORTS & $\begin{array}{c}\text { Share of primary goods export } \\
\text { in total exports }\end{array}$ & - (negative) \\
\hline LOGREAL_INTEREST & $\begin{array}{c}\text { Real interest rate (Selic policy rate } \\
\text { deflated by the consumer } \\
\text { inflation index) }\end{array}$ & - (negative) \\
\hline LOGREER & Real effective exchange rate & + (positive) \\
\hline LOGTARIFF & Average import tariff & $+/$ - (ambigous) \\
\hline LOGOPEN & $\begin{array}{c}\text { Degree of trade openess } \\
\text { (Exports plus imports/GDP) }\end{array}$ & $+/$ - (ambigous) \\
\hline
\end{tabular}

Source: Elaborated by the authors.

\footnotetext{
${ }^{15}$ See Carneiro's book (2002), which presents a detailed analysis of this period and also quotes several other studies that support this conclusion.
} 
The variables share of employment in the services of low skilled labor in total employment, share of primary goods export in total exports, are inspired in McMillan and Rodrik's model. They are expected to show a negative sign. In the first case, the migration of workers towards low-skilled occupations has negative effects on productivity growth as high skilled workers tend to perform their work at higher productivity. Yet the share of primary goods export in total exports captures the dynamic engagement in international trade. It would be expected that when exports of more technologically sophisticated products dominate total exports, productive structure is more technologically developed, and, therefore, the structural component of productivity growth would be positive. These two variables are related to the hypotheses raised in the previous sections to explain the stagnation of the productivity growth in Brazil in the recent period, that is, the occurrence of premature deindustrialization through which there has been a sharp reallocation of labor from both primary and manufacturing sectors to segments of low productivity and low skilled labor in the service sector.

The inclusion of the real interest rate captures a particularity of the Brazilian macroeconomic scenario, which is characterized by persistent high levels of the real interest rate when compared with other developing and developed economies. In this case, the expected sign is negative, given that high real interest rates, by adversely affecting the cost of real capital assets, inhibit long-term investment, the component of aggregate demand associated with the process of structural change.

Also, aiming at bringing to the model another specificity of the Brazilian macroeconomic policy, we add the real effective exchange rate, which plays an important role in the Brazilian monetary policy in the period, as its main transmission mechanism. ${ }^{16}$ In this case, it would be expected a positive correlation with the structural component of the productivity growth, ${ }^{17}$ for, as suggested by the theoretical and empirical literature, a bit undervaluation of domestic currency in real terms would boost exports and accelerate real GDP growth..$^{18}$ It is worth observing that these two variables are also in agreement with the hypothesis raised in the theoretical section that the performance of labor productivity growth is influenced by macroeconomic policies pursued by the Brazilian economy that adopted a very orthodoxy arrangement of monetary, fiscal and exchange rate policies since the mid-1990s.

The last two explanatory variables added in the model are average import tariff and the degree of trade openness of the economy. The argument is that a greater exposure of the domestic economy to international competition is fundamental to boosting aggregate productivity growth; however, some empirical evi-

\footnotetext{
${ }^{16}$ See on the topic Barbosa Filho (2015), Araújo et al. (2018), among many others.

${ }^{17}$ We define the exchange rate as the domestic price of a foreign unity (say, the Brazilian real per US dollar). Then, an increase of the exchange rate means a depreciation of domestic currency, while a decrease means an appreciation.

${ }^{18}$ For a theoretical demonstration, see Ros (2013, ch.11), and for empirical evidence, see Dollar (1992), Rodrik (2008) and Berg and Miao (2010).
} 
dence has shown that lower tariffs and greater trade openness may or not imply labor productivity growth. ${ }^{19}$ Thus, the expected signs of these variables in the model are ambiguous.

In order to identify the relationships between the explanatory variables and the inter-sectorial productivity component, the correlations were estimated using the Ordinary Least Squares (OLS) method. Table 2 summarizes the results in which the structural change component is the dependent variable.

Table 2: Determinants of the weak structural change and stagnation in Brazil's productivity: 1995-2011 Dependent variable: the structural change component

\begin{tabular}{|c|c|c|c|}
\hline $\begin{array}{c}\text { Variable } \\
\text { C }\end{array}$ & $\begin{array}{c}\text { Model 1: OLS } \\
\text { coefficients } \\
\text { (Statistics } t \text { between } \\
\text { brackets) } \\
-2.026 \\
{[-0.41]}\end{array}$ & $\begin{array}{c}\text { Model 2: OLS } \\
\text { coefficients } \\
\text { (Statistics t between } \\
\text { brackets) } \\
-2.870^{*} \\
{[-1.64]}\end{array}$ & $\begin{array}{c}\text { Model 3: OLS } \\
\text { coefficients } \\
\text { (Statistics t between } \\
\text { brackets) } \\
-2.085^{*} \\
{[-1.88]}\end{array}$ \\
\hline LOGLABORSHARE & $\begin{array}{l}-0.343 \\
{[-0.18]}\end{array}$ & & \\
\hline LOGOPEN & $\begin{array}{l}0.566^{*} \\
{[1.84]}\end{array}$ & $\begin{array}{l}0.598^{* *} \\
{[2.45]}\end{array}$ & $\begin{array}{l}0.524^{* *} \\
{[2.56]}\end{array}$ \\
\hline LOGPRIMARYEXPORTS & $\begin{array}{c}-0.738^{* * *} \\
{[-3.12]} \\
\end{array}$ & $\begin{array}{c}-0.745^{* * *} \\
{[-3.36]}\end{array}$ & $\begin{array}{c}-0.725^{* * *} \\
{[-3.40]} \\
\end{array}$ \\
\hline LOGREAL_INTEREST & $\begin{array}{c}-0.160 * * \\
{[-2.08]}\end{array}$ & $\begin{array}{c}-0.161 * * \\
{[-2.20]}\end{array}$ & $\begin{array}{c}-0.163^{* *} \\
{[-2.31]}\end{array}$ \\
\hline LOGREER & $\begin{array}{c}0.873^{* * *} \\
{[3.20]}\end{array}$ & $\begin{array}{c}0.853 * * * \\
{[3.59]}\end{array}$ & $\begin{array}{c}0.797 * * * \\
{[3.75]}\end{array}$ \\
\hline LOGTARIFF & $\begin{array}{l}0.192 \\
{[0.57]}\end{array}$ & $\begin{array}{l}0.157 \\
{[0.59]}\end{array}$ & \\
\hline
\end{tabular}

***: Significant at $1 \%$ level; **: significant at $5 \%$ level; * : significant at $10 \%$ level.

Source: Estimated by the authors according to the OLS model.

Model 1 presents the results with all the explanatory variables suggested in Table 1. Four variables were significant to explain the structural change component of the productivity growth in the 1995-2011 period: degree of trade openness and

\footnotetext{
${ }^{19}$ Edwards (1997) concludes that more open countries have indeed experienced faster productivity growth. Yet Gustafsson and Segerstrom (2008: 3) reach counterintuitive results: they show that "the overall effect of trade liberalization on productivity growth depends on whether intertemporal knowledge spillovers in R\&D are relatively weak or relatively strong. When these spillovers are relatively weak, then trade liberalization promotes productivity growth in the short run and makes consumers better off in the long run. However, when these spillovers are relatively strong, then trade liberalization retards productivity growth in the short run and makes consumers worse off in the long run".
} 
real effective exchange rate, both with positive sign as expected, and share of primary goods export in total exports and real interest rate with negative sign, as expected. In Models 2 and 3 these variables were also significant, and the coefficients of the variables very close.

We interpret that all the models capture that the greater exposure of the domestic economy to international competition would be a key variable to boosting aggregate productivity growth, through the component structural change. Actually, in terms of exports of goods and services as percentage of GDP, Brazil's degree of openness in 2017 was $12.5 \%$, rather low when compared to other countries such as China (19.8\%), India (19.1\%), Russia $(26.0 \%)$, South Africa $(29.8 \%)$ and South Korea $(43.1 \%) .{ }^{20}$

Also, the undervaluation of the real exchange rate contributes positively to the structural change component of the productivity between 1995 to 2011. Actually, this variable showed the highest coefficient in all models. ${ }^{21}$

Model 1 also shows that an increase in the share of primary goods export in total exports decreases the structural change component of the productivity, contributing negatively to explain the dependent variable. Finally, the negative sign of the real interest rate coefficient shows that the contractionary monetary policy conducted by the Brazilian Central Bank for a long period of time, by augmenting costs in real capital assets, contributes to reducing economic growth and productivity in the period. This reinforces the hypothesis initially stated that the adverse macroeconomic scenario was partly responsible for the stagnation of labor productivity of the Brazilian economy, in particular that related to its structural change component.

The variables average import tariff and share of employment in the services of low skilled labor in total employment were not significant in our first regression. Because of that, we regressed two other models: one without the variable share of employment in the services of low skilled labor in total employment (Model 2) and another without both the variables average import tariff and share of employment in the services of low skilled labor in total employment (Model 3). All variables maintained the expected signs and no significance, which reinforces the results of the first model.

To sum up, all the three regression models showed that the weak structural change and the stagnant labor productivity growth in Brazil between 1995 and

\footnotetext{
${ }^{20}$ Data on trade openness of these countries were drawn from the World Bank database, https://data. worldbank.org/indicator/NE.EXP.GNFS.ZS. Accessed on February 14th, 2019.

${ }^{21}$ It should be mentioned that one of the most quoted papers that investigates the relationship between the real exchange rate behavior and labor productivity growth is Dollar's (1992). The author asserts that a more competitive real exchange rate encourages firms that operate in the tradable goods sector to invest and seek technological innovations, acting in the direction of boosting their static and dynamic efficiency. This finding is in line with the theoretical argument developed by Bresser-Pereira $(2016,2019)$ that in developing economies not only sustainted aggregate demand matters, but also access to demand through a competitive real exchange rate.
} 
2011 were mainly explained by the overvaluation trend of the Brazilian domestic currency, followed by the high concentration of primary goods in the Brazilian export basket, by Brazil's low degree of trade openness and, finally, by the high real interest rates that prevailed in the period.

\section{CONCLUDING REMARKS}

Firpo and Pieri (2016: 269), replicating the same McMillan and Rodrik's (2011) methodology of decomposition of labor productivity in Brazil concluded that "structural changes have become less important to explaining productivity growth in the Brazilian economy than in the past, mainly because Brazil is an emerging economy, with a relatively diversified industrial sector, but with a relatively low level of labor productivity". As seen in this paper, our interpretation for the loss of importance of the structural component to explaining productivity growth goes in a distinct direction. Taking into account that Brazil has neither reached an economic maturity stage nor caught with rich countries' high per capita income levels yet, misleading economic policies has been one of the most important factors responsible for Brazilian labor productivity underperformance and long-term economic stagnation. Therefore, recent low GDP growth results should be analysed in light of the great regression in the productivity structure with negative consequences on productivity growth for the total economy. In this sense, growth recovery should focus on re-industrialization and macroeconomic policies should focus on stimulating productive investment to enhance productive growth.

Indeed, as shown in this paper, the sharp change in economic policy orientation in the 1990s and onwards had a deep impact on the structural change process, leading to premature deindustrialization. In fact, while in the period 1950-1979, labor productivity increased $4.4 \%$ per year and employment $3.3 \%$ per year, during the period 1980-2011, labor productivity was negative (at - $0,2 \%$ per year) and employment grew $2.2 \%$ per year. Besides, figures indicate that the reallocation of labor was sharply directed towards services of low skilled labor, even in the period of vigorous economic growth (1950-1979).

In light of this, our investigation took the following steps. First, we analyzed the theoretical issues related to structural change, economic development and longterm stagnation in countries that suffer from premature deindustrialization. Next, we presented a review on economic policies adopted in Brazil since the 1950s. Our empirical investigation in fourth and fifth sections followed McMillan and Rodrik's (2011) methodology. In the fourth section, we decomposed the Brazilian labor productivity growth in the period 1950-2011, according to structural change and within components. The exercise was reproduced for the subperiods 1950-1979 (heavy industrialization and sustained growth period) and 1980-2011 (the stagnant period). Our calculations showed that the structural change component was the most important to explain productivity growth in the period 1950-1979, and less 
important in the period 1995-2011, considering that in the period 1980-1994 productivity growth rate was negative.

In the fifth section, we use three econometric regression models to investigate the main factors explaining the structural component of Brazil's labor productivity stagnation since 1995. Our econometric exercise showed that Brazil's weak structural change and economic stagnation since the mid-1990s is mainly explained by the overvaluation trend of the Brazilian domestic currency (the Brazilian Real), followed by the high concentration of primary goods in the Brazilian export basket, then by Brazil's low degree of trade openness and, finally, by the high real interest rates that prevailed in the period.

Therefore, our empirical results suggest that misleading economic policies have been one of the most important factors responsible for Brazilian labor productivity underperformance and long-term economic stagnation. This means that the period during which the labor productivity growth became stagnant coincided with a weak harmonization between industrial policy with the macroeconomic regime, especially after 1999, when Brazil adopted a very orthodox arrangement of monetary, fiscal and exchange rate policies.

\section{REFERENCES}

Abreu, M.P. (2004). “Trade liberalization and the political economy of protection in Brazil since 1987". Working Paper-SITI-08B. Buenos Aires: Institute for the Integration of Latin America and the Caribbean (IDB-INTAL).

Amsden, A. H. (2001). The rise of "the Rest": challenges to the West from Late-Industrializing Economies. Oxford: Oxford University Press.

Araujo, E.; Araujo, E. L.; Ferrari-Filho, F. (2018). Monetary institutions and macroeconomic performance in Brazil after the inflation targeting regime: theoretical aspects and empirical evidence. Investigación Económica, Vol. LXXVII, nº 304, Abril-Junio/2018, pp.72-101.

Bacha, E. (2013). Bonança externa e desindustrialização e desindustrialização: uma análise do período 2995-2011. In: E. Bacha and M. B. de Bolle (orgs). O Futuro da Indústria no Brasil: Desindustrialização em Debate. Rio de Janeiro: Civilização Brasileira:97-120.

Baily,M.N. and Bosworth,B.P. (2014). US Manufacturing: Understanding Its Past and Its Potential Future. Journal of Economic Perspectives. Vol. 28, no.1, Winter: 3-26.

Barbosa-Filho, N. H. (2015). O desafio macroeconômico de 2015-2018. Brazilian Journal of Political Economy, Vol. 35, no. 3 (140): 403-425.

Berg, A. and Miao, Y. (2010), "The real exchange rate and growth revisited: the Washington Consensus strikes back?”, IMF Working Paper $n^{\circ}$ 10/58. Washington: DC: International Monetary Fund.

Bhagwati, J. (1978). Anatomy and Consequences of Exchange Control Regimes. Cambridge, MA: Ballinger Pub. Company.

Bresser-Pereira, L. C., Oreiro, J. L. and Marconi, N. (2014). Developmental macroeconomics: new developmentalism as a growth strategy. London: Routledge.

Bresser-Pereira, L.C. (2008). Dutch disease and its neutralization. Brazilian Journal of Political Economy, Vol. 28, no.1 (109): 47-71.

Bresser-Pereira (2016). Reflecting on new developmentalism and classical developmentalism. Review of Keynesian Economics, Vol.4, no.3, Autumn: 331-352.

Bresser-Pereira, L. C. (2019). Novo Desenvolvimentismo, 2018, in Feijo, C and Eliane A. (orgs). Macro- 
economia Moderna: as Lições de Keynes para economias em desenvolvimento, Elsevier, Associação Keynesiana Brasileira.

Carneiro, R. (2002). Desenvolvimento em crise: a economia brasileira no último quarto do Século XX. São Paulo: Editora UNESP.

Castilho, M. and Miranda, P. (2017)."Tarifa aduaneira como instrumento de política industrial: a evolução da estrutura de proteção tarifária no Brasil no período 2004-2014 e sua comparação com outros países”. Brasilia: Instituto de Pesquisa Econômica Aplicada (IPEA), unpublished paper.

Coutinho, L., Ferraz, J.C., Nassif, A. and Oliva, R. (2012). "Industrial policy and economic Transformation”. In: J. Santiso and J. Dayton-Johnson. Oxford: Oxford University Press:100-132.

Dixon, R and Thirwall, A. (1975). A Model of Regional Growth-Rate Differences on Kaldorian Lines, Oxford Economic Papers, vol. 11.

Dollar, D. (1992). Outward-oriented developing economies really do grow more rapidly: evidence from 95 LDCs, 1976-1985. Economic Development and Cultural Change, Vol. 40: 523-544.

Edwards, S. (1997). “Openness, productivity and growth: what do we really know?” NBER Working Paper Series WP 5978. Cambridge, MA.

Feijo, C and Carvalho, P. G. (2002). Uma interpretação sobre a evolução da produtividade industrial no Brasil nos anos noventa e as 'leis'de Kaldor. Nova Economia, Vol. 12: 57-78.

Firpo, S. and Pieri, R. (2016). "Structural change, productivity growth, and trade policy in Brazil. In: M.McMillan, D. Rodrik, and C. Sepúlveda. Structural change, fundamentals, and growth: a framework and case studies. Washington, DC: International Food Policy Research Institute: $267-$ 292.

Gala, P. (2008). Real exchange rate levels and economic development: theoretical analysis and econometric evidence. Cambridge Journal of Economics, Vol. 32, n² 2, Oxford University Press:273-288.

Gustafsson, P. and Segerstron, P. (2008). "Trade, liberalization and productivity growth". Stockholm School of Economics. Unpublished paper.

Kaldor, N. (1966). Causes of the slow rate of economic growth of the United Kingdom: An Inaugural Lecture. Cambridge, UK: Cambridge University Press.

Krugman, P. and Taylor, L. 1978. Contractionary effects of devaluation. Journal of International Economics, Vol. 8: 445-56.

Kume, H., Piani, G. and Souza, C.F.B. (2000). “A política brasileira de importação no período 1987-98: descrição e avaliação”. Rio de Janeiro: Instituto de Pesquisa Econômica Aplicada (IPEA), unpublished paper.

Kupfer, D. (2005). “Tecnologia e emprego são realmente antagônicos?” In: J. Sicsú, L.F. de Paula e R. Michel. Novo Desenvolvimentismo: Um projeto nacional de crescimento com equidade social. São Paulo: Ed. Manole.

McCombie, J. S.L. and Thirlwall, A. P. (1994). Economic growth and the balance-of-payments constraint, London: St Martin's Press.

McMillan, M.S. and Rodrik, D. (2011). "Globalization, structural change and productivity growth". NBER Working Paper Series 17143. Cambridge, MA: National Bureau of Economic Research.

Michaely, M. M., Papageorgiu, D., and Choski, A. (1991). Liberalizing foreign trade: lessons of experience in the Developing World. Vol.7. Cambridge, MA: Basil Blackwell.

Moreira, M.M. (1995). Industrialization, Trade and Market Failures: The Role of Government Intervention in Brazil and South Korea. London: Macmillan Press.

Nassif, A. (1995). "Política industrial e proteção no Brasil: o papel da CACEX". M.Phil. Dissertation. Niterói, Brazil: Universidade Federal Fluminense.

Nassif, A. (2003). Liberalização comercial e eficiência econômica: a experiência brasileira. Ph.D. Dissertation. Rio de Janeiro, Brazil: Instituto de Economia, Universidade Federal do Rio de Janeiro.

Nassif, A. (2005). "As fontes de mudança da eficiência técnica da indústria brasileira após a liberalização comercial: uma estimação econométrica por dados de painéis. Economia Aplicada Vol. 9 (1): Abril-Junho: 301-324.

Nassif, A. (2007). "National Innovation System and macroeconomic policies: Brazil and India in com- 
parative perspective”. UNCTAD Discussion Papers no. 184. Geneva: United Nations Conference on Trade and Development.

Nassif, A. (2008). Há evidências de desindustrialização no Brasil?, Revista de Economia Política, vol. $28, \mathrm{~N}^{\circ} 1$, São Paulo.

Nassif, A. and Castilho, M. (2018). "Trade patterns in a globalized world: the case of Brazil”. Working Papers 126. Rio de Janeiro: The Brazilian Development Bank (Banco Nacional de Desenvolvimento Econômico e Social - BNDES), November.

Nassif, A., Bresser-Pereira, L.C. and Feijó, C. (2018). The case for reindustrialisation in developing countries: towards the connection between the macroeconomic regime and the industrial policy in Brazil. Cambridge Journal of Economics, Vol. 42: 355-381.

Nassif, A., Feijó, C. and Araújo (2019). "Macroeconomic policies in Brazil before and after the 2008 global financial crisis: Brazilian policy-makers still trapped in the New Macroeconomic Consensus guidelines". Cambridge Journal of Economics, forthcoming.

Nassif, A., Feijó, C. and Araújo, E. (2017). A Structuralist-Keynesian model for determining the "Optimum” Real Exchange Rate for Brazil's economic development process: 1999-2015. CEPAL Review 123. December: 188-208.

Nassif, A., Feijó, C., and Araújo, E. (2015). Structural change and economic development: is Brazil catching or falling behind?. Cambridge Journal of Economics, vol. 39, no. 5: 1307-1332, 2015.

Oreiro, J. L. and Feijo, C. (2010). Desindustrialização: Conceituação, Causas, Efeitos e o Caso Brasileiro. Brazilian Journal of Political Economy, Vol. 30, no. 2: 100-115, Jan-Mar.

Palma, G. 2005. Four sources of de-industrialisation and a new concept of the Dutch disease. In Ocampo, J. A. (ed.), Beyond Reforms. Palo Alto: Stanford University Press: 71-116.

Rodrik, D. (2008), "The real exchange rate and economic growth". Brookings Papers on Economic Activity, Vol. 39, $\mathrm{n}^{\circ}$ 2. Washington, DC: The Brookings Institution.

Rodrik, D. (2011). “The future of economic convergence”. Working Paper 17400, NBER, September.

Rodrik, D (2016). "Premature deindustrialization”. Journal of Economic Growth, Springer, Vol. 21(1): 1-33, March.

Ros, J. (2013). Rethinking economic development, growth, and institutions. Oxford: Oxford University Press.

Rowthorn, R. and Ramaswamy, R. (1999). Growth, trade and de-industrialazition. IMF Staff Papers no. 46, 1. Washington D.C.: International Monetary Fund.

Thirlwall, A. P. (1979). The balance of payments constraint as an explanation of international growth rate differences. Banca Nazionale del Lavoro Quarterly Review, Vol. 128, 45-53.

Timmer, M. P., De Vries, G. J., and De Vries, K. (2014). Patterns of structural change in developing countries. Groningen Growth and Development Centre Research Memorandum 149. Groningen: University of Groningen, July.

Timmer, M. P., De Vries, G. J., and De Vries, K. (2015). "Patterns of structural change in developing countries". In: J. WEISS, and M. TRIBE (eds.). Handbook of Industry and Development. Routledge: $65-83$.

UNCTAD (2003). Trade and Development Report 2003: capital accumulation, growth and structural change. New York and Geneva: United Nations Conference on Trade and Development. 
Appendix

Description of data sources of estimated regressions on the fifth section

\begin{tabular}{|l|l|}
\hline \multicolumn{1}{|c|}{ Explanatory variables } & \multicolumn{1}{c|}{ Sources } \\
\hline $\begin{array}{l}\text { Share of employment in the services of low } \\
\text { skilled labor in total employment }\end{array}$ & $\begin{array}{l}\text { Groningen Growth and Development Center } \\
\text { database. }\end{array}$ \\
\hline Share of primary goods export in total exports & COMTRADE database \\
\hline $\begin{array}{l}\text { Real interest rate (Selic policy rate deflated by } \\
\text { the Consumer Inflation Index - IPCA) }\end{array}$ & $\begin{array}{l}\text { For Brazilian nominal policy interest rate } \\
\text { (SELIC): Central Bank of Brazil; } \\
\text { For Brazil's Consumer Inflation Index (IPCA): } \\
\text { Brazilian Institute of Geography and Statistics } \\
\text { (IBGE)/Sistema Nacional de Índices de Preços } \\
\text { ao Consumidor (SNIPC) }\end{array}$ \\
\hline Real effective exchange rate & $\begin{array}{l}\text { Brazil's Instituto de Pesquisa Econômica } \\
\text { Aplicada (IPEA) - Monthly Serie Taxa de } \\
\text { Câmbio Real Efetiva - Exportaçôes/Average } \\
\text { of 2000=100 }\end{array}$ \\
\hline Average import tariff & \begin{tabular}{l} 
Brazil's Foreign Trade Department (SECEX) \\
\hline $\begin{array}{l}\text { Degree of trade openess (Exports plus im- } \\
\text { ports/GDP) }\end{array}$
\end{tabular} \\
$\begin{array}{l}\text { World Development Indicators, 2017/The } \\
\text { World Bank. }\end{array}$ \\
\hline
\end{tabular}

